\title{
Bioavailability of ${ }^{99} \mathrm{Tc}$ to a macrophyte of the Yenisei River
}

\author{
L. Bondareva and A. Bolsunovsky \\ Institute of Biophysics, Siberian Branch of the Russian Academy of Sciences, \\ 660036 Krasnoyarsk, Russia
}

\begin{abstract}
The experiments on accumulation of ${ }^{99} \mathrm{Tc}$ by Elodea biomass showed that ${ }^{99} \mathrm{Tc}$ activity concentration can reach $120 \pm 6 \mathrm{~Bq} / \mathrm{g}$, with the concentration factor for ${ }^{99} \mathrm{Tc} 2700 \pm 500 \mathrm{~L} / \mathrm{kg}$. In experiments on ${ }^{99} \mathrm{Tc}$ release, over $504 \mathrm{~h}$ about $82 \%$ of the total ${ }^{99} \mathrm{Tc}$ activity was released into the water from plant biomass; most of ${ }^{99} \mathrm{Tc}$ was released within the first $192 \mathrm{~h}$. Results of chemical fractionation of the biomass show that ${ }^{99} \mathrm{Tc}$ contained in biomass was mainly concentrated in the exchangeable and the adsorbed fractions (83\%). Thus, the data obtained using chemical fractionation of biomass confirmed the experimental data on ${ }^{99} \mathrm{Tc}$ release, which suggested that most of the biomass-bound ${ }^{99} \mathrm{Tc}$ was adsorbed on the biomass surface. ${ }^{99} \mathrm{Tc}$ tightly bound to Elodea biomass (fractions of organics and mineral residue) constituted just $17 \%$ of the total ${ }^{99} \mathrm{Tc}$ activity. Decreased illumination of Elodea shoots during the experiment did not cause any reduction in ${ }^{99} \mathrm{Tc}$ activity concentration or concentration factor. Results of chemical fractionation of the biomass grown under lower illumination conditions show that the percentage of ${ }^{99} \mathrm{Tc}$ tightly bound to Elodea biomass (fractions of organics and mineral residue) decreased while the ${ }^{99} \mathrm{Tc}$ of the adsorbed fractions decreased. Our results and data reported by other authors suggest that some part of ${ }^{99} \mathrm{Tc}$ activity can be bioavailable to living organisms and that the portion of bioavailable ${ }^{99} \mathrm{Tc}$ can be determined by a number of factors.
\end{abstract}

\section{INTRODUCTION}

Technetium-99 is a long-lived artificial radionuclide with a half-life of $2.13 \times 10^{5}$ years, which poses a considerable environmental hazard. The major sources of ${ }^{99} \mathrm{Tc}$ in the environment are fallouts from atmospheric nuclear weapon tests and releases from nuclear fuel reprocessing operations and accidents at nuclear plants. Another source is nuclear medicine, which uses ${ }^{99 \mathrm{~m}} \mathrm{Tc}$ (decaying into ${ }^{99} \mathrm{Tc}$ ) although its contribution is much less important than the other sources. The Mining-and-Chemical Combine (MCC) situated in the Krasnoyarskii Krai [1] includes a radiochemical plant for reprocessing nuclear fuel and, thus, one can assume that large amounts of ${ }^{99} \mathrm{Tc}$ are contained in radioactive waste and are partly released into the Yenisei River ecosystem with MCC effluents. Investigation of ${ }^{99} \mathrm{Tc}$ behavior in model ecosystems can yield data for predicting its behavior in the Yenisei River.

The purpose of our study was to obtain data on accumulation and release of ${ }^{99} \mathrm{Tc}$ by biomass of Elodea canadensis, one of the abundant species of submerged plants in the Yenisei River, in laboratory experiments.

\section{MATERIALS AND METHODS}

Experiments were conducted in laboratory, using Elodea canadensis Mich. (waterweed) - a submerged plant occurring in the Yenisei River. Plant and water samples were collected from the Yenisei River upstream of the MCC discharge point. Plant samples were taken from the population growing in one of the river inlets. In our experiments we used $3.2-3.5 \mathrm{~cm}$ apical shoots. The plants were pre-washed with the river and tap water. The Yenisei River water was aseptically filtered through $0.2-\mu \mathrm{m}$-pore-size cellulose nitrate membranes $(\mathrm{d}=47 \mathrm{~cm}$, Shleicher\&Shuell, Germany) to remove suspended particles and microflora. The plants were maintained in $0.2 \mathrm{~L}$ of water in $0.25-\mathrm{L}$ cylindrical glass vessels, at a temperature of $17-19^{\circ} \mathrm{C}$. Half of the vessels were illuminated by luminescent lamps during $12 \mathrm{~h}$ a 
day and the side irradiance of a vessel was $4.5 \mathrm{klx}$; then they were used in the "day/night" experiment. The remaining vessels were enveloped in foil and kept in near darkness; they were used in the "night" experiment. The parameters of radionuclide accumulation by plants were calculated per unit of dry weight. ${ }^{99} \mathrm{Tc}$ was added to the water as a solution of $\mathrm{TcO}_{4}^{-}$(in the presence of a $0.1 \mathrm{M} \mathrm{HNO}$ solution). The added solution of ${ }^{99} \mathrm{Tc}$ was neutralized with a $\mathrm{NaOH}$ solution $(0.1 \mathrm{M})$ to $\mathrm{pH} 7.0$. Then, plants were placed into the water. Experiments on accumulation of ${ }^{99} \mathrm{Tc}$ by Elodea shoots lasted 6 days each. To estimate ${ }^{99} \mathrm{Tc}$ release from Elodea, we took the plants out of the experimental vessels at a stage of maximal ${ }^{99} \mathrm{Tc}$ concentration in the biomass and placed them into vessels filled with the clean Yenisei water $(0.25 \mathrm{~L})$. The experiment on ${ }^{99} \mathrm{Tc}$ release lasted 21 days. During the ${ }^{99} \mathrm{Tc}$ accumulation and release experiments, at set intervals, aliquots of water and plant shoots were analyzed for the ${ }^{99} \mathrm{Tc}$ concentration. Accumulation of radionuclides in plants is often characterized by a distribution coefficient or bioconcentration factor, generally called concentration factor $(\mathrm{CF})$. CF relates to (pseudo) equilibria between the radionuclide concentration in organisms and that in the water, as summarized by definition:

$$
\mathrm{CF}=\frac{\text { Concentration of the radionuclide in the organism, } \mathrm{Bq} / \mathrm{kg} \text { dry } \mathrm{wt}}{\text { Concentration of the radionuclide in the water, } \mathrm{Bq} / \mathrm{L}}
$$

To calculate parameters of ${ }^{99} \mathrm{Tc}$ accumulation by Elodea, we used the averaged data for three experimental vessels with Elodea shoots.

To estimate the mobility of ${ }^{99} \mathrm{Tc}$ contained in the plant, we used the method of sequential chemical extraction [2]. Technetium of the exchangeable fraction was separated by exposing the plant biomass to the action of a $\mathrm{CH}_{3} \mathrm{COONH}_{4}$ solution $(1 \mathrm{M})$ for $24 \mathrm{~h}$. To separate ${ }^{99} \mathrm{Tc}$ of the adsorbed fraction, the plant biomass was treated with a $\mathrm{H}_{2} \mathrm{SO}_{4}$ solution $(0.2 \mathrm{M})$ for $20 \mathrm{~min}$. The ${ }^{99} \mathrm{Tc}$ that was still retained by the biomass was considered to be strongly bound to plant components. ${ }^{99} \mathrm{Tc}$ bound by organic compounds and mineral residue of the plant biomass was separated by "wet combustion", using $\mathrm{H}_{2} \mathrm{O}_{2}(30 \%)$ and a $\mathrm{HNO}_{3}$ solution $(0.1 \mathrm{M})$.

${ }^{99} \mathrm{Tc}$ in water samples of the "Elodea - Yenisei River water" model system and in the biomass fractions was measured using a Tri-Carb-2800 liquid scintillation analyzer (USA), with $\sim 100 \%$ registration efficiency for ${ }^{99} \mathrm{Tc}$. Aliquots of water and liquid fractions were mixed with a Hi-Safe-2 scintillation cocktail in $20-\mathrm{ml}$ plastic vials at a ratio of 8 to 12 . Prior to measurements, the resulting mixtures were left to stabilize in the dark at $\mathrm{t}=8-9^{\circ} \mathrm{C}$ for $48 \mathrm{~h}$. The longest measurement time was $420 \mathrm{~min}$. The chemical composition of the Yenisei water used in the experiments was analyzed in the Analytical Laboratory of the Institute of Biophysics SB RAS, using Carl Zeiss equipment: an emission spectrometer, a FLAPHO-4 flame photometer, and an AAS-IN atomic absorption spectrometer (Table 1). Anion content of the water was determined using a TsVET-3006 ion chromatography system at the Department of Analytical Chemistry of the Siberian Federal University.

Table 1. Elemental composition of the Yenisei River water.

\begin{tabular}{|c|c|c|c|c|c|c|c|c|}
\hline & $\mathrm{Na}$ & $\mathrm{Mg}$ & $\mathrm{Al}$ & $\mathrm{Si}$ & $\mathrm{S}$ & $\mathrm{K}$ & $\mathrm{Ca}$ & $\mathrm{Sr}$ \\
\hline $\mathrm{mg} / \mathrm{L}$ & $2.2 \pm 0.1$ & $3.6 \pm 0.4$ & $0.17 \pm 0.02$ & $3.8 \pm 0.3$ & $3.1 \pm 0.6$ & $0.58 \pm 0.03$ & $19 \pm 3$ & $0.29 \pm 0.01$ \\
\hline & $\mathrm{P}$ & $\mathrm{Cr}$ & $\mathrm{Mn}$ & $\mathrm{Fe}$ & $\mathrm{Co}$ & $\mathrm{Ni}$ & $\mathrm{Cu}$ & $\mathrm{Zn}$ \\
\hline$\mu \mathrm{g} / \mathrm{L}$ & $10.3 \pm 0.6$ & $1.5 \pm 0.2$ & $2.5 \pm 0.2$ & $35 \pm 2$ & $0.25 \pm 0.05$ & $2.1 \pm 0.4$ & $2.4 \pm 0.2$ & $7.1 \pm 0.6$ \\
\hline
\end{tabular}

\section{RESULTS AND CONCLUSIONS}

\subsection{Accumulation of ${ }^{99}$ Tc by Elodea canadensis}

Typical dynamics of ${ }^{99} \mathrm{Tc}$ activity concentrations in the water environment are shown in Figure 1 . The dynamics of water depletion of ${ }^{99} \mathrm{Tc}$ in the "day/night" and "night" experiments are similar. During the first $24 \mathrm{~h}$ Elodea rapidly took up ${ }^{99} \mathrm{Tc}$ (accumulating about $20 \%$ of the added activity) and then, 


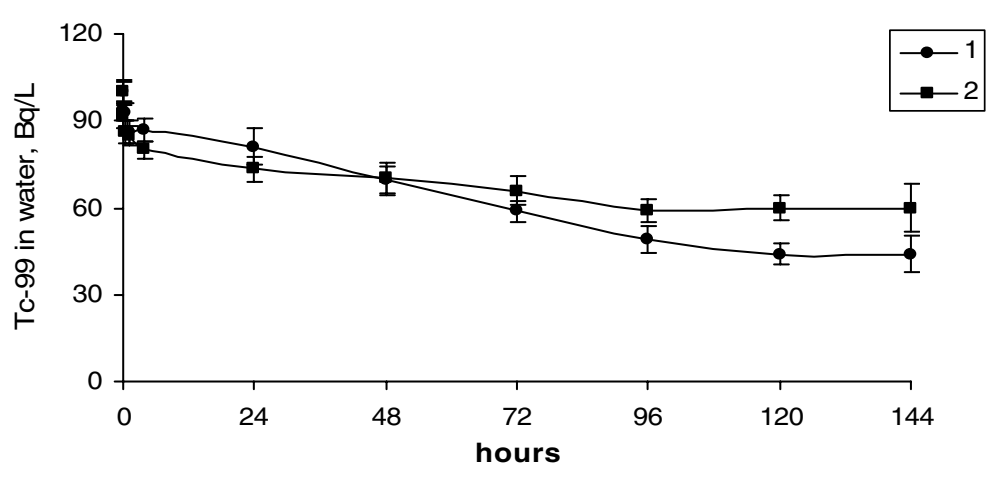

Figure 1. Dynamics of the added ${ }^{99} \mathrm{Tc}$ activity in the water of experimental vessels $(\mathrm{Bq} / \mathrm{L}): 1$ - "day/night" experiment, 2 - "night" experiment.

for 4 days, the water was gradually depleted of the radionuclide. At day 6 differences between ${ }^{99} \mathrm{Tc}$ activities in the water of experimental vessels were not significant: $44 \pm 6 \mathrm{~Bq} / \mathrm{L}$ in the "day/night" experiment and $60 \pm 8 \mathrm{~Bq} / \mathrm{L}$ in the "night" experiment. ${ }^{99} \mathrm{Tc}$ activities accumulated in plants differed depending on the experimental conditions (Table 2). In our experiments activity concentration of ${ }^{99} \mathrm{Tc}$ in Elodea samples was $120 \pm 10 \mathrm{~Bq} / \mathrm{g}$ dry wt in the "day/night" experiment and $170 \pm 11 \mathrm{~Bq} / \mathrm{g}$ dry wt in the "night" experiment (Table 2). The maximum technetium CF for Elodea was calculated to be $2700 \pm 500 \mathrm{~L} / \mathrm{kg}$ dry wt ("day/night"), which was comparable to the concentration factor obtained in the "night" experiment (Table 2). By the end of the experiment both the plant mass and the shoot length had increased. That, however, had changed the mass of the dried plants very little. As radionuclide activity accumulated by the plants during the "day/night" and "night" experiments was inversely related to the weight increase, we arrived at the following conclusion. The radionuclide activity was almost totally concentrated in the 3.2-3.5-cm part of the shoot, which had been initially used in the experiment. Our values for ${ }^{99} \mathrm{Tc} \mathrm{CF}$ (Table 2) are considerably different from the values obtained in other studies for freshwater model systems: 25-300 L/kg dry wt. [3]. However, J. Hattink and his co-authors in their study used Lemna minor L. (common duckweed), a submerged plant whose morphology is different from that of Elodea $[3,4,8]$. In our earlier experiments with submerged plants we showed that ${ }^{99} \mathrm{Tc}$ concentration in the plants is determined by the mechanism of radionuclide accumulation. We found at least two major mechanisms of accumulation. One of them is homeostatic regulation of accumulation, i.e. Tc is an analogue of an element that is vitally important for the plant. We observed the action of this mechanism in our experiment, when ${ }^{99} \mathrm{Tc}$ concentration in the water varied proportional to concentrations of the anions $\mathrm{Cl}^{-}$and $\mathrm{SO}_{4}^{2-}$ (Fig. 2). Hence, in our system anions can be considered as analogues of ${ }^{99} \mathrm{Tc}$, which usually occurs in the water as $\mathrm{TcO}_{4}^{-}$. The other mechanism is Tc control by the radionuclide concentration in the environment. Brown and his co-authors reported [5] that under the conditions of continuous inflow of ${ }^{99} \mathrm{Tc}$ the CF for Fucus vesiculosus amounted to $10000 \mathrm{~L} / \mathrm{kg}$ dry wt, with the ${ }^{99} \mathrm{Tc}$ concentration in the water $1-4 \mathrm{~Bq} / \mathrm{m}^{3}$. On the other hand, a single addition of a large concentration of ${ }^{99} \mathrm{Tc}$ can yield large CFs, too. For instance, Russian specialists of the Mayak nuclear complex conducted experiments with Elodea [6], adding high ${ }^{99} \mathrm{Tc}$ activity $\left(10^{6}-10^{10} \mathrm{~Bq} / \mathrm{L}\right)$ for spectrophotometric detection, with the plant mass being relatively small: $15 \mathrm{~g}$ fresh wt. The highest CF that they obtained amounted to $50000 \mathrm{~L} / \mathrm{kg}$ dry wt. However, in those experiments, Elodea plants, as well as plants of several other species, died at days 10-15 of the experiment. A reason for the death of the plants can be that ${ }^{99} \mathrm{Tc}$ is chemically toxic to living organisms, similarly to $\mathrm{Cr}(\mathrm{VI})-\mathrm{CrO}_{4}^{-}$[7]. Moreover, the presence of considerable amounts of ${ }^{99} \mathrm{Tc}$ was reported to cause radiation intoxication in plants [8]. The adverse effect of ${ }^{99} \mathrm{Tc}$ on plants was exhibited in their decreased growth and concentration of chlorophylls. Toxicity symptoms in the form of chlorosis and necrosis developed. 
In our experiments we added $100 \mathrm{~Bq} / \mathrm{L}$ of ${ }^{99} \mathrm{Tc}$, and plants developed well throughout the experiments the shoots grew rapidly.

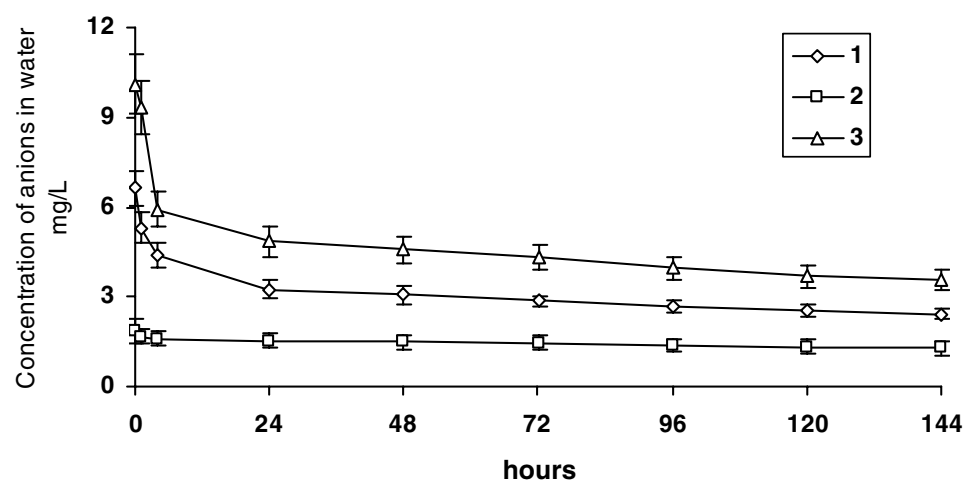

Figure 2. Dynamics of anion concentrations in the water of the experimental system: $1-\mathrm{SO}_{4}^{2-}, 2-\mathrm{NO}_{3}^{-}, 3-\mathrm{Cl}^{-}$.

Table 2. Results of experiments on ${ }^{99} \mathrm{Tc}$ accumulation by Elodea canadensis.

\begin{tabular}{|c|c|c|c|c|c|c|}
\hline \multirow[t]{2}{*}{$\begin{array}{l}\text { Condition } \\
\text { of experiment }\end{array}$} & \multicolumn{2}{|c|}{$\begin{array}{c}\text { Dry mass, } \mathrm{g} \\
\text { Fresh mass, } \mathrm{g} \\
\text { (shoot length } \mathrm{cm} \text { ) }\end{array}$} & \multicolumn{3}{|c|}{$\begin{array}{c}\text { Equilibrium activity } \\
\text { of }{ }^{99} \mathrm{Tc}\end{array}$} & \multirow{2}{*}{$\begin{array}{c}\text { Concentration } \\
\text { factor, } \\
\mathrm{L} / \mathrm{kg}\end{array}$} \\
\hline & Initial & Final & $\begin{array}{c}\text { In plants, } \\
\mathrm{Bq}\end{array}$ & $\begin{array}{l}\text { In plants, } \\
\text { Bq/g } \\
\text { dry mass }\end{array}$ & $\begin{array}{c}\text { In water, } \\
\mathrm{Bq} / \mathrm{L}\end{array}$ & \\
\hline "day/night" & $\frac{0.082 \pm 0.03}{1.31}$ & $\begin{array}{c}\frac{0.095 \pm 0.004}{2.33} \\
(7.3 \mathrm{~cm})\end{array}$ & 11.4 & $120 \pm 10$ & $44 \pm 6$ & $2700 \pm 500$ \\
\hline "night" & $\begin{array}{c}\frac{0.082 \pm 0.003}{1.31} \\
(3.4 \mathrm{~cm})\end{array}$ & $\frac{0.081 \pm 0.002}{1.88}$ & 8 & $170 \pm 11$ & $60 \pm 8$ & $2850 \pm 450$ \\
\hline
\end{tabular}

Note: The table lists the averaged data for three experimental vessels with Elodea shoots.

\subsection{Release of ${ }^{99} \mathrm{Tc}$ by Elodea canadensis}

To determine the strength of binding of ${ }^{99} \mathrm{Tc}$ in Elodea, we performed experiments on ${ }^{99} \mathrm{Tc}$ release. As mentioned above, to estimate ${ }^{99} \mathrm{Tc}$ release from the biomass, we took the plants out of the experimental vessels and placed them into vessels filled with the clean Yenisei water. The initial ${ }^{99} \mathrm{Tc}$ activity in Elodea in the vessels was $3.8 \pm 0.2 \mathrm{~Bq}$ per vessel (the "day/night" experiment) and $2.6 \pm 0.2 \mathrm{~Bq}$ per vessel (the "night" experiment). The typical dynamics of ${ }^{99} \mathrm{Tc}$ activity in the water of the vessels containing the plants are shown in Figure 2. In the "day/night" experiments, in $24 \mathrm{~h}$ after Elodea shoots were placed into the vessels with the filtered water, we were able to register some ${ }^{99} \mathrm{Tc}$ activity in the water environment (Fig. 2). During the following days of experiment, the ${ }^{99} \mathrm{Tc}$ activity in the water increased, reaching saturation at $192 \mathrm{~h}$. Then, from $192 \mathrm{~h}$ to $504 \mathrm{~h}$ no increase in ${ }^{99} \mathrm{Tc}$ activity in the water was registered, i.e. no ${ }^{99} \mathrm{Tc}$ was released by plant biomass. ${ }^{99} \mathrm{Tc}$ activity concentration in Elodea samples decreased over the course of the experiment from 120 to $22 \mathrm{~Bq} / \mathrm{g}$ dry wt; the dry weight of Elodea remained almost unchanged, although the shoots became twice longer. In the "night" experiments, ${ }^{99} \mathrm{Tc}$ was detected in the water in $24 \mathrm{~h}$ (Fig. 3). ${ }^{99} \mathrm{Tc}$ activity concentration in Elodea samples decreased over the course of the experiment from 170 to $61 \mathrm{~Bq} / \mathrm{g}$ dry wt. In addition to ${ }^{99} \mathrm{Tc}$ natural release, rapid 
biomass destruction was also observed, leading to gradual separation of plant segments containing the ${ }^{99} \mathrm{Tc}$ that they had accumulated before.

Analysis of our results suggested the following. The radionuclide is taken from the water layer into the plant due to electrostatic interactions between $\mathrm{TcO}_{4}^{-}$anions and the charged ions on Elodea surface. As a result, a double electric layer is formed, which is favorable for ${ }^{99} \mathrm{~T}$ accumulation in the surface layer of the plant and its further transfer across plasma membrane by $\mathrm{Cl}^{-}, \mathrm{SO}_{4}^{2-}$ transporters. Thus, considerable release of ${ }^{99} \mathrm{Tc}$ from the biomass into the water registered in this study suggests that most of the ${ }^{99} \mathrm{Tc}$ bound by biomass is adsorbed on the surface of Elodea plants.

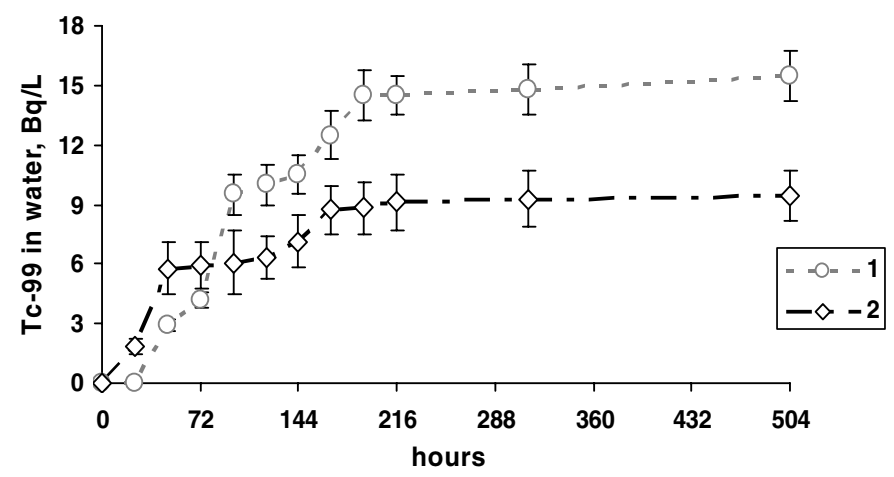

Figure 3. Dynamics of ${ }^{99} \mathrm{Tc}$ release from the Elodea shoots to the water $(\mathrm{Bq} / \mathrm{L})$ of experimental vessels: 1 - "day/night" experiment, 2 - "night" experiment. The initial ${ }^{99} \mathrm{Tc}$ activity in Elodea: $3.8 \pm 0.2 \mathrm{~Bq}$ per vessel (the "day/night" experiment) and $2.6 \pm 0.2 \mathrm{~Bq}$ per vessel (the "night" experiment).

\subsection{Mobility of ${ }^{99} \mathrm{Tc}$ in plant biomass}

The assumption of the mobility of ${ }^{99} \mathrm{Tc}$ accumulated by plant biomass can be verified by determining the strength of ${ }^{99} \mathrm{Tc}$ binding to the plant. Our hypothesis that biomass-bound ${ }^{99} \mathrm{Tc}$ is mostly found in the surface layer is confirmed by the data on the distribution of ${ }^{99} \mathrm{Tc}$ in biomass fractions, which have been obtained using chemical fractionation (Fig. 4). ${ }^{99} \mathrm{Tc}$ tightly bound to Elodea (III+IV - the fractions of organics and mineral residue) constituted just $17 \%$ (the "day/night" experiment) and $31 \%$ (the "night" experiment) of the total ${ }^{99} \mathrm{Tc}$ activity. In this case, ${ }^{99} \mathrm{TcO}_{4}^{-}$must be biotransformed in cell organelles, e.g. in vacuoles, similarly to heavy metals, or in chloroplasts [9]. The fact that in the "night" experiment Fractions III+IV contained larger activities of the radionuclide can be accounted

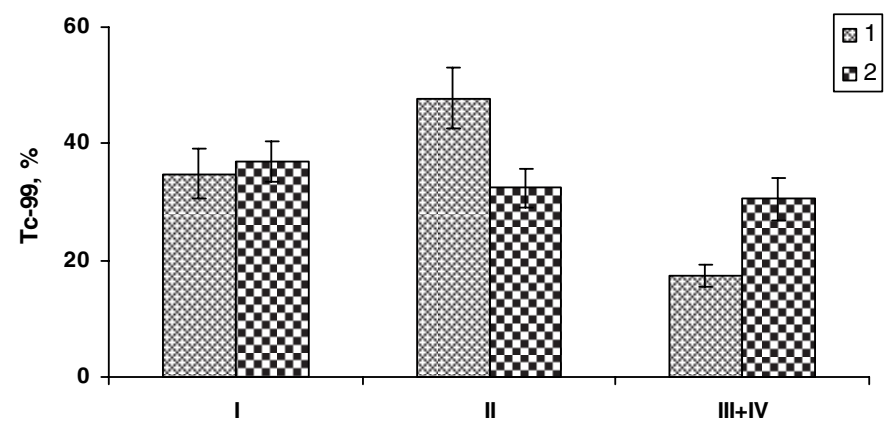

Figure 4. Relative distribution of ${ }^{99} \mathrm{Tc}$ among fractions of Elodea biomass (1 - "day/night" experiment, 2 - "night" experiment): I - exchangeable fraction; II - adsorbed fraction; III+IV - fractions of organics and mineral residue. 
for by partial destruction of the cell walls under near darkness conditions. That could cause a faster exchange between the cellular content and the aqueous medium of the experimental system. Thus, ${ }^{99} \mathrm{Tc}$ concentration in the biological structures of the plant was increased. These data suggest that ${ }^{99} \mathrm{Tc}$ may be incorporated into Elodea's cellular structures, mostly into cell membranes.

The experiments on accumulation of ${ }^{99} \mathrm{Tc}$ by Elodea showed that ${ }^{99} \mathrm{Tc}$ activity concentration can reach $120 \pm 6$ (the "day/night" experiment) and $170 \pm 7$ (the "night" experiment) Bq/g dry wt, with the maximum transfer factor for ${ }^{99} \mathrm{Tc} 2700 \pm 500 \mathrm{~L} / \mathrm{kg}$ dry wt. In experiments on ${ }^{99} \mathrm{Tc}$ release, over $504 \mathrm{~h}$ more than $60 \%$ of the total ${ }^{99} \mathrm{Tc}$ activity was released into the water from plant biomass; most of ${ }^{99} \mathrm{Tc}$ was released within the first $192 \mathrm{~h}$. Results of chemical fractionation of the biomass show that ${ }^{99} \mathrm{Tc}$ contained in Elodea was mainly concentrated in the exchangeable and the adsorbed fractions (83\% - the "day/night" experiment, 69\% - the "night" experiment). However, there was more ${ }^{99} \mathrm{Tc}$ directly bound to biomass in the "night" experiment than in the "day/night" one. The main reason for that was destruction of cell walls in the "night" experiment, which gave better chances for the radionuclide to penetrate into the cellular structures and be incorporated into them.

\section{References}

[1] Bolsunovsky A., Aquatic Ecology, 38, 57 (2004).

[2] Bolsunovsky A., T. Zotina, L. Bondareva, J. Environ. Radioactivity, 81, 33 (2005).

[3] Hattink J., H.T. Wolterbeek, J. de Goeij, Environ Toxicology Chemistry, 20, 996 (2001).

[4] Hattink J., J. de Goeij, H.T. Wolterbeek, J. Radioan Nucl. Chem. 249, 1, 221 (2001).

[5] Brown J.E. et al. Marin Pollution Bulletin, 38, 7, 560 (1999).

[6] Mashkin A.N., S.L. Shikov, Radiokhimiya (Radiochemistry), 42, 268 (2000).

[7] Prëvëral S., E. Ansoborlo, S. Mari, A. Vavasseur, C. Forestier, Biochimie, 88, 1651 (2006).

[8] Hattink J., L. Weltje, H.T. Wolterbeek, J. de Goeij, J. Radioan. Nucl. Chem., 259, 1, 135 (2004).

[9] Zenk M.N., Gene, 21, 179 (1996). 